\title{
Alternative Theoretical Foundations of Penal Sentences in Criminal Law with Regard to Iran's Islamic Penal Code 1392
}

\author{
Ahmad hamdamiyan ${ }^{1} \&$ Ahmad Reza Behniafar ${ }^{2}$ \\ ${ }^{1}$ Department of Law, Damghan Branch, Islamic Azad University, Damghan, Iran \\ ${ }^{2}$ Department of Islamic Thoughts, Damghan Branch, Islamic Azad University, Damghan, Iran \\ Correspondence: Ahmad hamdamiyan, Department of Law, Damghan Branch, Islamic Azad University, \\ Damghan, Iran.
}

\author{
Received: February 21, 2016 Accepted: April 5, 2016 Online Published: April 27, 2016 \\ doi:10.5539/jpl.v9n3p40 \\ URL: http://dx.doi.org/10.5539/jpl.v9n3p40
}

\begin{abstract}
The failure of penalties depriving liberty in the social rehabilitation of offenders and to reduce the jail population and prevention of recidivism and reduce the costs of implementing the policy of freedom depriving punishment sentence depriving freedom of recent decades and the United Nations was considering legal systems.In depriving Iran from its initial rounds of legislative measures to restrict the scope of punishment was considered free.since 1370 substitution of alternative measures of punishment now widely spread than ever before converting a penalty in the form of suspension of its operation are available depriving of freedom.

Alternatives to punishment of imprisonment in the Penal Code in 1992 was taken into consideration in the new Penal Code in 1392 in addition to the previous alternatives of new cases of alternative punishment of prison is considered that including the daily fine, public services and care period pointed out.
\end{abstract}

Keywords: imprisonment, penalty, punishment, freedom

\section{Introduction}

Freedom bond that has been established with the creation of man in him that due to its importance in human life is privileged to have the rights on the enjoyment of other human rights include withdrawal. Therefore, in all systems and communities as fundamental rights recognized in international conventions such as the Universal Declaration of Human Rights and the International Covenant on Civil and Political Rights and the recognition and respect has always been emphasized. In addition, the exercise of this right has a significant impact on human development and the flourishing of communities, but improper use of it and going to extremes in its territory could have led to problems and abnormalities. Therefore, the scope and conditions of the laws of the country itself. Thus, the law may impose limitations on the freedom of individuals to be predicted. The law provides criminal penalties for illegal deprivation of liberty of individuals is known.

Given the role that freedom plays in people's lives restriction or deprivation as a guarantee of respect for the norms and values of communities has long been regarded as the most common means of dealing with offenders shame and suffering because of it can be terrorize and provide deterrence and compensation commission error.

\section{Chapter One: The Definition of Imprisonment, Nature and Manner of Punishment of Imprisonment and Its Characteristics}

\subsection{Statement of the Problem}

Penalties against criminals always seen as the community reaction to the developments in order to achieve a suitable means of defense of human rights and social security. There is no doubt that the law of each country has evolved through the efforts of scholars and teachings of penology and the determination and the use of warranty various measures have been applied in different periods.penalty freedom depriving punishments is also important that this process is no exception. With regard to this a punishment depriving liberty is one of the most common criminal, the question is whether this one ofovensisstill the best instrument for social defense against? Otherwise, what other measures can be replaced, it can be predicted that without its disadvantages, using them to meet the objectives of the social rights achieved correction and prevention of recidivism?

Penological experts criminal law and to protect human freedom and social adjustment offenders studied this 
issue and measures to be speculated. The foundations of the subject by addressing these issues will be examined: 1. Is Iran criminal policy replacement tendency implies imprisonment in the criminal realm? 2. If so, what methods are used to this policy? 3. measures as an alternative to imprisonment What is expected? In this research highlights what he views Iran's criminal policies to penalize alternative measures depriving of freedom and judicial and legislative analysis of aspects of it.

\subsection{The Definition of Imprisonment in Iran}

One of the most significant achievements of schools and new thinking about the nature and goals of criminal punishment, but the lead-strong prison. It was a penalty. The new penal institution viable alternative to corporal punishment and inhumane was the past.

With the implementation of the sentencehas been committed for some time and risk exclusion from society for society, Goes (keep the social and public order) and that did not threaten their own through (Protection of the rights of the accused and convicted of crimes against victims or other persons as well as preserving evidence) and that can be classified inmates andcorrectional methods specific to the prison of the vulnerability of the people and social (a personal goal of reform and opening up the penalties and the socialization of the perpetrators).

Term imprisonment in Persian in both sensesinfinitive, the punishment of imprisonment and sentenced to a criminal's whereabouts is used as a prison. Prison words in both Arabic and Farsi means jail where the punishment is imprisonment. Two words in the original Arabic Prison are in prison and have been used in the Quran. For example, the term Msnvjyn in Chapter 26 (poets) used in verse 29 where Pharaoh says to Moses: "if you worship a god other than meimprisoned Knm-" La Jlnk I Almsnvjyn "other derivatives prison in various verses of Surah Yusuf (12) is frequently used. the verses 25: 32-33-35-36-39-41-42-100, the term of imprisonment Two times in the Qur'an in Surah used one of eleven verse 8 where God says, "If we punish ask them to postpone, what it stop And-a Mayhsbh. "Anotherverse 106 of Chapter 5 is about the will to permit maintenance of a witness is giving testimony.

\subsection{The Nature of The Punishment of Imprisonment}

The concept of any form of imprisonment and the deprivation of liberty is called a title run. Despite his foreign worlds of communication between prisoners, such as using the phone - especially cell phones and computers by the defendant mentioned in Article 11 "temporary detention center bylaw" - meet, even in a private meeting leave (the first three chapters of part III "prisons regulations 1384" and some other freedoms 229-189 materials for the prisoner, the punishment of imprisonment compared to other types of punishment-based restrictions free to take legal affairs to its people, "depriving freedom" means the stripping is called absolute freedom. Therefore, any other restrictions for individuals who commit violations are not limiting or depriving freedom-limiting and depriving them of rights will be.

\subsubsection{Criminal Nature of Imprisonment (Stripping Restrictions Freedom)}

At first glance appear imprisonment and even in nature is a kind of punishment. Because this action not only against the wish and will of the individual and is one of the characteristics of punishment and reward,but the prison, to the constraints created and imposes on him who would otherwise not valid and acceptable, and no one likes to be subject to it. This is a feature of all punishment as a result of implementing them type of restriction, ranging from the finance or psychological, Goftari or of conduct for the rights or reputation or dignity of human life or freedom would be.

As can be seen history that shaped their sentences be reviewed in the past with the present face different penalties, but in both cases, and restrictions imposed for the issue of a penalty, which is obvious OPEN.

\subsubsection{Coercive Nature of Prison Properties}

However, compulsion and imposition of any punishment, including imprisonment or imprisonment general characteristics of each type of deprivation of liberty is the purpose nature of the force produced but here is another thing. In many cases, individuals as to the extent or immediate punishment, etc. they report to prison,but in many of these cases, it is not a financial one sentence ranging from debt - either in cash or Mal- restitution or a fine, but refuses to pay or does not have the ability or he established and debility is not known. The same goes for someone who was on bail or bail, and so it has not or does not sponsor or collateral. In such cases, the person sentenced to punishment of imprisonment with a legal limit or Strengthening of the or hinder - but with a prisoner is placed under pressure to pay or be refunded as soon as funds or property, or collateral and guarantee reliable order to introduce the.. 


\subsection{Forms of Punishment in Prison}

In order to qualified fifth courts and how the revised of the rules applicable to persons convicted of depriving freedom as well as the intensity of the committed offense punishable by imprisonment classification should be used. Protect the rights and fundamental freedoms are criteria in the diagnosis of the sentence dictates. Therefore, penal systems based on the severity of punishment, detention and punishment of crimes categorized depriving of freedom with many of theseare: short-term and long-term imprisonment punishment.

\subsection{Properties Punishment of Imprisonment}

Punishment in order to compensate for the errors committed and the establishment of social order and public heal the principles of justification of punishment, including imprisonmentis being considered. Ndamtga Spanishare also characteristics of this sentenceis due." The supposed offender in the penitentiary mental austerity and hardships clean and decent and moral man he becomes."

Jeremy Bentham based on the principle of criminal involvement suffering and loss calculations supplier knows the purpose of deterrence and punishment imposed involves real suffering and pain of punishment emerges knows apparent in terms of the human imagination. And the suffering people of the appearance that can must stop committing crime is actually more suffering as much as possible.

Tags imprisonment for offenders together is not always even after the penalties depriving liberty and the property of efforts on the reform of the offender influenced. Relatives and people from the association refused to condemn Sv'pyshynh in terms of the Job shunned the as a result of being deprived of normal benefits, and often the way to take the life of crime.

\section{Season Two: Goals, Benefits, Specifications and Conditions of Use Substitutes Bag of Confinement and Alternative Punishment of Prison}

Alternative programs sentence of the objectives, benefits and specifications and conditions are also provided in this topic,as the two speech about the objectives and benefits of alternatives to imprisonment, featuresand conditions alternatives to detention generally, will be described.

\subsection{Objectives Alternative Criminal Sentences}

The selection and implementation of alternative methods canbe said that different purposes are involved, including the objectives are:

1. Elimination or reduction of objection to the punishment of imprisonment.It is a general purpose that includes all the drawbacks of the punishment is imprisonment. For example, the widespread use of imprisonment increases the jail population,increased economic costs and so on.

2. The implementation and reproducible sentenced the community in order to avoid harmful consequences of imprisonment that is tearing society. The use of alternative methods to facilitate the creation of a position in the community for offenders Is that your social status among family members, friends and community re-gain.

3. better enforcement of justice. In consideration of alternatives to imprisonment meant the abandonment of the prison and Sai Traditional punishment, but rather an attempt to more complete and diversify their criminal judges have options. In this case,justice runs better. Because the judges for a variety of Crimeand enforcement, appropriate options at their disposal.

So, prison should only be applied to criminals that their release would endanger public safety and rehabilitation re little hope of reform and not to the community. Pursue the goals that alternative sanctions are deemed to be criteria for evaluating their value. Although various alternatives have the same value, but each part to play in achieving the goals of the penal system.

\subsection{The Benefits of Alternative Criminal Sentences}

Use alternative methods, including their benefits include:

1. Theuse of prison as a last resort to violence the alternative punishment on a large scale not only ensures the security community, but also compliance with human rights and human dignity, the costs will be considerably reduced the criminal justice.

2. Inflation criminal population and lack of prison space and the problems that this causes in the possibility of reform and rehabilitation and re-treatment of prisoners arebrought prevented.

3. consequently reduce the jail population, the cost of the judicial system and reduces the overall community.

4. Theuse of alternative recidivism is reduced and the possibility of reform and opening again he provides to the 
community.

\subsection{Features of Alternative Criminal Sentences}

Alternatives to imprisonment can be taken into account features that include:

1. The criminal replace imprisonment, Lyale that bad or criminal sentence or after sentencing at the time penalty will be raised. Therefore, alternatives to detention are outside the scope of our discussion.

Some believe that Kyfrhbs alternatives, only the criminal verdict and the verdict are outlined.

2. Alternative methods of confinement, a symbol and a manifestation of the principle of individualizing the penalty or penalties that same coordinate its implementation with regard to the character of the offender, the type of crime, criminal record, number and frequency of crime (principle fitness).

3. Alternative methods of confinement are conspicuous symbol of a criminal policy partnership.

4. Alternatives violent character,the punishment is imprisonment for less. That Akhf are more of imprisonment.

5. Alternative methods of confinement, sentenced to deprivation of liberty should not be sentenced to withdraw from society, Not. It restrictionsas punishment for convicts work in some capacity.

6. shell alternative methods of imprisonment, requiring regulatory procedures and care in order to reduce the risk of re-offense is convicted. So that, for example, the responsibility of social workers, only report violations and defianceof orders, but they also have an obligation to punish those convicted of this type of assistance in adopting a dignified life and seek to eliminate barriers to social rehabilitation Barayand.

\subsection{The Fourth Topic: Alternative Terms of Criminal Confinement}

To be a successful and efficient replacement policies have a series of conditions and structures needed for effective implementation. Otherwise the effective implementation failed and failed, or in other words, alternative methods of clay Smoke and function sprior to lose. these terms and structures include:

\subsubsection{Culture Necessary}

Implement effective alternative methods of punishment of imprisonment requires preparation and its culture among various segments of society and is responsible organizations involved in implementing this approach. Knowledge and understanding of the status and performance of alternative methods of detention, those methods is an essential condition for acceptance and successful implementation of such a program unless the different strata of society and the responsible institutions and conflict, the methods adopted and of its support. Acculturation and its acceptance in the judicial system (in other words awareness and understanding of the judges of performance and function alternatives) is also a necessary condition. For example, the judges will be trained in the use of large-scale prison and acceptance of punishment of imprisonment as the principal punishment, especially when it is not necessary (in case of non-dangerous offenders and according to the circumstances of the offense and the offender, victim compensation and...), should be avoided.

To institutions and individuals responsible for implementing these programs, performance and function using alternative methods is also to be understood as, for example, the implementation of many social penalties require the participation and cooperation of the people andin the community is non-governmental organizations the possibility of capacityin the community - to open a better implementation of efficient re-offenders to community and alternative methods - benefit. For example, public services, community and non-governmental institutions such as municipalities and public service delivery institutions charged with accepting and offering job opportunities, participate in the execution of punishment or in the course of care may monitor the behavior of the sentenced person to prevent recidivism and report violations to the one of his close friends and relatives to be trusted. So, individuals and entities involved in implementing these programs, whether official or non-governmental should understand and have sufficient knowledge of the status and performance of alternative plans because the successful implementation of these programs requires cooperation and participation of individuals and organizations and institutions are properly informed andis. Otherwise, the implementation of these programs will fail.

\subsubsection{Having Specific and Explicit Legal}

The effective and efficient implementation ofalternative methods in addition to culture, we need legislation clear and unambiguous. The task of the legislator, the law imposes a clear and decisive Vsryh kind of alternative approachand how to choose and implement the individuals and entities responsible for the implementation of these programs and determine the duties and obligations which they are, and so on. 


\subsection{The Alternative Forms of Punishment in Prison}

\subsubsection{First Speech: Replacing the Traditional Punishment of Imprisonment}

Traditional alternatives include probation, suspension penalty, fines and penalties of deprivation of social rights.

\subsubsection{Parole}

Parole is a tool and leniency before the end of the period prescribed by the sentencing court sentence that reflects the special attention granted to the sentenced person legislator to reform and open treatment of social adjustment is doomed. Of means parole part ofbreeding programs, educational and social Bazsazgary social facilitator is the person in the community.

Parole can be used as an alternative incarceration program - in the broad sense - understood; if it is accompanied by monitoring Otherwise the alternative described by giving it to some extent be a problem with here. Because, when the practices and alternative programs to incarceration is considered to be a criminal nevertheless.

In the new Penal Code 1392 Chapter VIII of the conditional release system 57 to 62 refer to the conditions and manner of granting conditional release stated.

\subsubsection{Suspension Penalty}

In principle to a definitive conviction and sentencing comes to the implementation of the definitive sentence But the execution looks at the causes and conditions stipulated by the law may be delayed. The suspension is meant to deter and delay the suspension of rights to criminal penalties do not count, but also as a tool for the offender, and assist in leniencyis givento the court. The suspension penalty brought the school from realization (proof) is sentenced to detention and the conditions under which the criminal is particularly difficult punish it and it will be saved drawbacks. At p.M. The new 1392 Chapter SIX suspension agreement implementation of the punishment prescribed by Articles 45 to 54 is inferred.

\subsubsection{Fine}

Fine of one financial penalty is sometimes the main punishment (eg Article 541 BC.M.Of) and sometimes complementary punishment or Ttmymy mandatory (Article 707 BC.M.Of) or optional (Article 708 BC.M.Of) the a court order is placed. fine-functioning that one of themis a substitute's role. in other words, the application of penalties, fines or replacement What independently discerning between what the punishment conversion - that in many countries, including Iran, it is used as punishment for criminals.

Fine in BC.M. Of newalternatives to punishment of imprisonment in 1392 in the 63 is included as one of the 85 also has a certain amount of a fine alternative to imprisonment.

\subsubsection{Loss of Civil Rights}

The punishment of deprivation of civil rights of the new initiative, which is used in some countries and can be used as an alternative to imprisonment. We in this part of the loss of civil rights, including those dealing means. In other words, limiting penalties depriving liberty or employment rights and social rights and public services, all of which refers to the deprivation of their deprivation of social rights.

The punishment of deprivation of civil rights, the means, including, inter dependent Nyzvajd principles governing criminal penaltiesthat have objectives such as the prevention of crime, reform and rehabilitation of offenders, observing the principle of individual sentences,avoiding imprisonment in economically, decriminalization and are in prison.

Loss of civil rights, however, has been described as criminal but as one of the measures that are mostly hedge "In fact, the main purpose of fall prevention strategies condemned this crime by creating obstacles in carrying out criminal activity and removing him from the Environment he is to have that aspect of crime."

In BC.M.Of new legislation in 1392 as one of the alternative punishment of deprivation of social rights put the 86 stipulates imprisonment.

\subsubsection{Second Speech - New Substitute Punishment of Imprisonment}

New Alternatives in prison with the adoption of the rights of other countries in the world as well as social Penal Code Include surveillance period, daily fines, public services.

\subsubsection{Concept of Care}

You can take care of this as: Adelay penalty to the offender and his freedom for a certain period under the supervision and control of the probation officers and correctional treatment he provides guidance and background on an individual basis or of social care is a punishment that the offender is obliged under the care of 
an officer or a social worker care period,the conditions specified by the court to do.

\section{Goals}

The most important goals of care are:

-Re-offender rehabilitation and prevent re-offending by farthe most important of correctional facilities and treatment. (This The mainpurpose ofprobation is to reduce the risk of recidivism can also protect society and provide support.)

-Alternative to prison sentences than those offenders who are exposed to serious risks The prison.

-For overseeingand monitoring the behavior of offenders and thereby protecting society.

-Reduce overcrowding.

\section{Territory}

Volume care about all crimes (small, medium and important) is applicable, except in some countries and in the case of serious crimes (such as rape rape, theft, serious bodily injury, murder) was not applicable or subject tothe circumstances. We remind that at the end of the period of applicability of care in children (under 18 years) and adults there.

\section{Term Care}

Usually duration of care to the importance of Crime and the Treatment depends on the person. Time for the grant of care is different in different countries.Some countries may consider the minimum and maximum care for the period. The average duration of care, in most countries,approximately 6 and 12 months and a maximum of 36 and 60 months.

In the period of care in Iran. 82 states:

1. In those punishable by imprisonment up to 6 months of their legal maximum of 3 months.

2. In crimes involving legal punishment of 91 days to 6 months imprisonment and the punishment of crime and the type is not specified in the statutory six months to a year.

3. In those punishable byimprisonment for up to one year'slegal up to 6months 1 to 2 years.

4. unintentional crimes that legal punishment is imprisonment of more than one year 2 to 4 years.

\subsubsection{Daily Fine}

Punishable by a fine in terms of problems that arise in its implementation and sentenced to prison in the event of insolvency is to be made punishable by a fine of not only failed mission and function as a punishment to the success of actions to bebut the importance of modern function fine as punishment for "alternative sentences" is reduced. Therefore, the scholars to reduce objections, a new way of punishment for fair fines have suggested that the implementation of its daily fines (fines daily) is.

This approach is useful not only for daily fines of administrative problems but also reduces fine adjuster to fine some other drawbacks as well.

Add thatto adaily fine penalty is a conspicuous symbol of respect for the individual.

\section{Adaily penalty goals and benefits}

\section{Goals}

The main objectives of the sanction imposed daily fines to appear include:

- As an alternative to imprisonment, tobe criticism that the punishment is imprisonment Enter.

- As an alternative to punishment is fine until modulators are some problems and drawbacks of the fine.

\section{Benefits}

As an alternative to imprisonment penalty of a daily fine independent and enjoys the following benefits that include:

- Reduce the rate of recidivism.

- Daily fine punishment, not The only costis for the government but also for government revenue.

- Inalienable society and family, especially his condemnation of economic activity.

- Avoid causing offense being sent to the prison environment 
- This guarantees the implementation of educational reforms to bring stable. Because sentence against every day feels heavy and limitations of penalties and monthly payment every time a new warning to condemn the.

- Preventing the flow of people unable to pay fines to prison

- Fair and equitable way to implement this type of enforcement

\section{Conditions for Granting and Implementation of a Daily Fine}

Court for sentencing to a daily fine and its implementation requires compliance with a series of rules and regulations, which include:

1. He was sentenced income and living expenses to consider.

2. The court also fined for granting daily should also consider the severity of the crime.

For this reason, some judges believe that the amount of the fine is determined on the basis of two criteria or in two stages: "First, the judge depending on the type and importance of the crime,the number of days to pay the fine within a legal range (minimum and maximum) defines.in the second stage, the judge in proportion to the offender's income,the amount of the daily penalty is determined, ie, the sum of daily income to provide him some expenditures exclude the offender and his family and the rest of the fine as it is deduction. then the amount deducted from the daily income of a number of days before the intended crime, and this figure multiplied by the total penalty to the offender must pay,determined.

3. Sentenced person shall, within the time specified in the orderto pay the fine in installments. If the sentenced By misses out on certain days, to pay the fine in installments, with the expiration of the period specified payments had been fined and sentenced Since the moment of its debt, unable to pay not be sent to prison.

Social Penal Code Article 23 provides: "At the end of each month sentenced person must pay the fine within ten days.In case of failure to pay within the grace period without a valid reason, sentenced to judge the implementation of social punishment remains Azayrvz hay was held.the court issued a warrant against the informed this arrangement is explicitly mentioned and condemned."

Note sentenced person can pay all or part of daily fines together.

Article 24 of the bill provides: "If you do not pay daily fines due Drmhlt of reasonable excuse, thejudge another deadline for the payment of the social penalty or converts it to punish the other social."

Enforcement not to pay daily fines, imprisonment for the remaining days of payment.

\section{The Daily Fine in the Criminal Law of}

The daily fines as surveillance period, unfortunately in Iranian criminal law since the legislation (in 1304) up to now, has not passed any rules.

Producers bill "social punishment" for the first time indaily fines referred to punishment.

Daily fines of63BC.M. The new 1392 is considered as one of the alternative punishment is imprisonment.

The 84 BC.D. The new daily fine amount and conditions require it. Daily fines is until the Sentenced daily income...)

\subsubsection{General Services}

Another name for the public service, "utility services" and "social services" that are synonymous with each other in terms of meaning.

Public Serviceand replaceone form ofsocialpunishmentis imprisonment Is to do something for the benefit of society and to be free.

Article 16 of the Social Penal Code provides that: "Public services without receiving wages, the court ordered the sentenced person for the benefit of the community."

Penalty public services or public utility services as a societal independent and alternative punishments in some cases imprisonment is accepted in most countries. This punishment is not only without dangers and disadvantages of prison, but improve the economic, social, cultural and educational as well.

Public service (work)of the doomed, synonymous with unemployment and forced labor, but also sentenced to rehabilitation and reform of the way to avoid negative Azasar prison sentence, taking advantage of the capacities of rehabilitation, employment and compensation of public due to the damage that criminals commit crimes in the 
community have been.

Article 16 of the Social Penal Code provides that: "Public services without receiving wages, the court ordered the sentenced person for the benefit of the community."

\section{A-goals and benefits of public services}

\section{Goals}

One of the most important public service objectives forecasts penalties include:

1. avoid adverse psychological and social effects of prison.. With the explanation that employment in the public of the dangers and risks of short-term prison sentences reduced and prevents contact with the dangerous offenders, as well as professional and family and social disintegration of the obstacle should be punished by.

2. increase the likelihood of Bazsazgary and reform of the offender.

3. Reduce the risk of recidivism.

4. Compensation victim and the community by doing something useful for society and utilizing community ofhis activities and thereby reducing the economic downturn.

5. Increased sense of responsibility and confidence Drmjrm.

6. curb rising prison population and thus reduce its cost.

\section{B-Terms and implementation of public services}

For the verdict to punish the public service and its implementation and regulatory conditions intended that the framework conditions common in most countries is the same. These include:

1. Thestatus of the offender in terms of age, gender, physical and mental abilities and skills of the person must be considered. Because the kind of work that considers judicial authority for sentence against him should firstly according to age and gender. Second, theresentenced person to have the ability to do work.they also have the expertise and skills needed.

2. Thetype of sentence the sentenced person must consent to carry out the work, which the Public Service of punishment, physical and mental limits leads Therefore, the sentenced person must be satisfied to implement it. Because rehabilitation and otherwise there modified.

3. condemnation case against the formation of character.

4. The penalty of judicial institutions and public services requires awareness and participation of local institutions, public and civil institutions. So the punishment, a conspicuous symbol of the criminal policy and participation. Because, active and effective implementation of public service reform and the treatment of offenders required public participation, and civic and educational institutions, and advertising via mass media and judicial and others. We also have a real desire, and ability to accept work where the offender institution be established.

5. specialized and experienced individuals to perform community service punishment.

6. The Court must hours and the length of time that the sentenced person must pay to provide public services, specify.

Article 17 of the Social Penal Code provides that: "The time and duration of the public service are as follows:

A crime where the maximum punishment of six months imprisonment or flogging is immediate, from 40 to 100 hours and the crimesthat the maximum punishment is imprisonment up to 6 months to 2 years,and also in cases of discounts...From 100 to 480 hours.

(B) the maximum duration of the public service is 18 months.

\section{C-the public service in Iran Criminal Law}

Unfortunately, so far the Iranian criminal law relating to public service rules and regulations have not punished according to the law the judge can sentence the offender to the punishment. But in practice (courtjudgments and Initiatives undertaken by the Prisons Organization) cases can be seen that the attention of judges and officials to be punished.

Alternative penalties in connection with a proposal by the Director General of Prisons of Mazandaran province that has been raised is significant and worthy of attention.

1) work in Agriculture and animal husbandry projects instead of prison 
2) Instead of prisonlabor inmining projects

3) Instead of prison labor in industrial projects

4) Working in business affairs instead of prison.

Iran now (during84-1383) measures developed by the Centre for Strategic Studies, Justice and the Supreme Judicial Council regarding the punishment of the public services and social described in Penal Code Articles 16 to 21 during the.

The 83 BC.M.Of New 1392 That the public service is free as one of the alternative punishment of prisonstates that free public services, the service is doomed for a certain time the actual sentence with the consent and under the supervision of the judge is implementation. The services the law free public in the 63's included.

\section{Chapter III: Factors Principles of Criminal Tendency to Substitute Imprisonment}

\subsection{Principles of Criminal Replace Prison}

\subsubsection{Doubt about the Position and Credibility of the Punishment of Imprisonment}

Although long mission of revenge and retribution, punishment, intimidation and protests were convicted but under the influence of criminological studies and humanitarian ideas and perspectives on the quality of social reaction against the criminal phenomenon has developed and presented new concepts and ideas. The punishment depriving liberty and retribution roles and social rehabilitation, deterrence and it has been changed and "at the end of the twentieth century anti-delinquency want to look at it only renders the final approach."

Protection of constitutional rights and freedoms of individuals and performance loss and change aspects of punitive penalties depriving freedom and flexibility, as well as hurt personal principles of freedom and equality and legality of depriving punishments would reduce the popularity and credibility of the were criminal systems.

Review and evaluate the objectives and characteristics of penalties depriving liberty and the principles governing the formation of political precondition for addressing how are liberty depriving sentence.

\subsubsection{Failure to Provide Penalty Goals}

Now that the other phenomena of human social and criminal phenomenon that various factors influence each play a role in its development. With the development of knowledge bases delinquency reaction against them became more important missions and have crystallization of human targets and the Role of were constructive. and ethical aspects of treatment and deterrence and securing the interests of the community are the most important purposes of criminal systems.

Freedom depriving punishments of retribution commission error rate and compare it with the intensity of damage on society to determine and justify. Forecast maximum and minimum sentences and judges the authority to determine the type of this allows the severity of the errors committed and the damage victim crime against society and the appropriate punishment of imprisonment for the country. However, this role also frequently retribution, is questionable. "those who committed injustice will feel punished punishment as a relatively small number and even rare.it on the contrary, these people know that crime in order to re-establish justice commit a criminal act to their detriment have been violated and punishment in this case, in their view as a favorite social compulsion considered even complementary injustice $»$.

Preventing crimeand repeat it in the role of inhibition achieved freedom depriving punishment. Undoubtedly, this deterrence by providing awareness to people about the reaction of law enforcement against delinquent acts and create fear in them, as well as a warning to the criminal and others it is done through the implementation of general prevention and prevention is one of the results. Nevertheless purpose of deterrence someone with less freedom depriving punishment and prison populations often corresponded with reality Tkrarknndgan constitute a crime.as long as the disadvantages prisonsor neutralization of fear and loss with its ugliness and probably corrupt prison inmate, professional, after its deterrence is flawed.the by-law passed in 1372 mandated prison, according to prison disadvantages that can cause serious obstacles in the prevention of Article 11 and 14 of Article 23, identify the causes and motivations of crime andcrime prevention methods as well as planning for care after leaving the prisoner and put the jobs of prison.

Rehabilitation is one of the most important goals of punishment depriving liberty with the objections of the eighteenth century onwards to poor prison conditions by scholars such as John Howard and Charles De Luca was a man of penalties depriving liberty and treatment of prisoners with a dramatic turn when school teachings were for personal realization and eliminate dangerous state criminal penalties for social reconstruction and Security and Corrective measures led to the formation of indeterminate punishments. 
School of Social Defense to develop fundamental freedoms and respect for the dignity and human dignity assistance and international treaties such as mandatory minimum rules concerning the treatment of prisoners, adopted amendments to the 1955 International Covenant on Civil and Political Rights by the United Nations General Assembly in 1966 to approved and signed by the Iranian government in 1354 passed the approval of parliament and human regulations for the punishment depriving liberty and security were developed breeding purposes and the treatment of the sentenced.

Although prevention and treatment aimed at correcting value in its own right, but the realities in the field of prison reform and treatment thought to have been disappointed.The prison terms for convicted nature due to the creation of reservations and restrictions that overshadowed the modification.If of and even leads to personality disorder and violence against the existing order.

The idea has caused the failure of remedies aimed at punishing some justification as it be deemed impossible. "It is impossible to justify the reform of the offender as punishment purpose. There are several reasons for this. First, the causes and circumstances of the crime and have little knowledge about how to change people's behavior and the loss of our information is limited their willingness to commit a crime.as a result of the implementation lack of knowledge about the criminal punishment inevitably leads to failure ». does the pursuit of new ways to improve and treatment that is applicable sanction in the community and social or replacement policy can be used for this purpose helpful.

\subsubsection{Lack of Coordination with the Principles Governing the Punishment}

Following evolution of criminal ideas of the eighteenth century thinkers such as Montesquieu thought then, and underand Rousseauand Beccaria principles and conditions for determining what punishment was suggested that eventually the Universal Declaration of Human Rights and Citizen of 1789 was adopted. These principles include: Principle legality,the principle of equality and the principle of personal punishment.

Based on the principle of legality determined only by the law and by the competent authorities will be punished.However aimed at reforming the punishment depriving liberty requires that the court according to the characteristics of the offender and the circumstances of the crime have within the minimum and maximum to evaluate and thus depriving punishments individual freedom with the legislative, judicial and executive functions have been combined.

Freedom depriving punishment of offenders for crimes they committed in similar circumstances on the basis of the principle of equality shall equally be applied.But actually its influence to different people.This penalty is punishment for noble souls of the social prestige. However, a stray people and homelessness is highly desirable. individualizing the punishment depriving liberty to apply mitigation, conditional suspension of punishment depriving liberty and freedom may be limited in practice the principle of equality of result.

According to the principle of personal freedom depriving punishment, punishment should be applied only to criminals. Article 7 AH.A.D. Seamless Iran stipulates: "The punishment is applicable only to the perpetrator and its partners. "However depriving punishment due to the nature of freedom actually affects the family and the family of the convicted.

With regard to the conditions mentioned in the penal systems development today are seeking to avoid the adverse effects of punishment depriving liberty and take other measures to meet the goals of the search that criminal penalty depriving of freedom are the difficulties and constraints no.

\subsubsection{Decriminalize Ideas}

However, as noted signs of decriminalize the prior criminal can be seen in schools, as Gramatyka has proposed to replace the concepts of mass, guilty, punish anti-social concepts of private and non-criminal measures to improve the human diverted to be used. Nevertheless «contemporary movement to stop the punishment of the end of 1960 and beginning of 1970 in absolute freedom was the continuation of an ideological movement "and from 1975 due to the huge number of criminal offenses in laws and lack of implementation or non-implementation of an important part of these rules restricting the movement penal system to provide the community through non-criminal ways of maintaining discipline was developed thinks.

The movement to decriminalize three stages, decriminalization and eventually the abolition of criminal lawin them.

"The first decriminalize which includes all forms of modification in the penal system, such as turning goats to mitigate the degree criminal Jnhhay or to make a substitution action rather than punishment depriving liberty."

This method has a mitigation of punishment may even include removal of criminal or non-criminal alternation 
between punishment and an act of the will. Therefore, measures to restrict criminal or remove it is placed in this territory.Such as: conversion of the punishment or you to place an act of a milder succession instead of punishment depriving liberty. decriminalize may result from legislative act is a judicial or administrative authorities.the legislator may be to a degree misdemeanor criminal offense of the possibility of reduced or converted into, or suspension or penalty under the terms of the prediction.from Non-prosecution or other judicial authorities described cessation of prosecution or criminal act in a way that becomes less important in achieving mass, and finally decriminalize play a pivotal role in the process of administrative, policy measures to decriminalize helps some people.for example, in some police intervention the matter and referred it to the other social systems. or Mjnylyh the announcement of the complaint or the prosecution and punishment of offenders is passed.

Now with regard to the government's desire to maintain alternative actions within the framework of the legal system and penal system to adjust its mass is more important in criminal law different countries with serious rethinking of the alternative measures are attention to decriminalize. as criminal law in 1975 Germany has a fine short-term substitute prison or a fine or semi freedom Act 1981 Italy has the authority to replace or release under supervision has estimated the judge. the law of June 10, 1983 in France, the daily fines and Enter the utility has the French penal system.

With regard to the role of officials or other persons responsible for criminal policy of territorial delimitation process and decriminalize decriminalize penalties depriving liberty to determine the types of Pay:

\subsubsection{Kyfrzd to Improve Legislative}

One of the ways penal sanction compliance with the terms and concepts of social reaction and create new values concerted effort to restrict,sanctions of the crime is considered by the legislator.Legislature through fundamental choices in the field of criminal policy prominent role to play. Mjnylyh've passed the legislature with the offenses envisaged by refusing to confirm or complaint peace and compromise with the accused in decriminalize opens.also expected to follow the rules, cessation and suspension of prosecution,punishment by law to suspend the implementation of mitigation and prosecution authorities,research, and judgment of it contributed to decriminalize. in some cases, the regulations are the wrong side of the powers of the executive powers of action in the past is no crime or punishment was however not established or misdemeanor, or misdemeanor contrary to become janabah.

The legislator may fulfill the new requirement is subject to fulfillment of a crime or a Tbryhknndh excuses or reasons attributable to the inability to predict or may be about the judge's charge on increased discount or exemption from punishment, or an alternative measure abdacting to punish its freedom, as it is possible rather than punishment and security measures foreseen or complementary punishment to punish criminal offense to remove or consequential punishment and finally may become optional supplementary legislation to decriminalize the possibility of imposing penalties, although on a limited basis provide, as foreseen the possibility of parole or semi-freedom or penalties such is the end of the week.

\subsubsection{Justice Decriminalize}

The role of judicial authorities in shaping policy and decriminalize its practical forms in certain cases is very important in this regard is the role of the court is important.

Community representative in the court of public prosecution and litigation and criminal prosecution court is essentially specific tasks. But parallel to prosecute the accused to the appropriate court of justice, the interests and rights of the accused and, therefore, also considers before issuing the indictment If you can forgive and GZsht complaining cessation of prosecution and incase of suspension of prosecution qualification issue.the court provided that the original position of having to be one of the most widely recognized forms due to decriminalize the criminal Tyb.

On the basis of the position of the prosecutor's prosecution before any action necessary or not necessary to examine the criminal prosecution and punishment of the offender if it is useful and social benefit to pursue it, and if the public aspect insignifi- crime and social interest is in failing to follow it no matter what it is.

Provisional filing of cases and misdemeanor crimes that are considered as criminal. Alternative methods from the original position of the prosecution is, the tracking measure in Article 22 of the law amending some laws passed in 1356 to the Prosecutor of Justice had been anticipated.

Using their role in the field of judicial interpretation of criminal policy violations,ambiguity and silence rules to effectively serve, as in the use of sanctions legislator has estimated the possibilities that can be used more or less wide day. 
Courts have interpreted narrowly in favor of the accused in cases of ambiguity or silence can not fulfill the circumstances of the crime and the mitigation of and excuses Mafknndh ruled the day. The sentence depriving freedom and security measures and educational measures and the use of complementary punishment withdraw or can at least guarantee crimes lose their significance or intended execution of the sentence suspended.as it can use its powers in the field of relief or exemption from punishment. "bail and adjourned sentencing two pre-arrest diversion of offenders from punishment. "

In the process of administrative and executive later stage of criminal proceedings may help some people to decriminalize policy, such as police intervention or prosecution or charges in some cases be taken apart and refrain from filing evidence.As' in the UK and Wales all those who are found guilty in a given year, not sent to court,the royal prosecutor's office may decide not to pursue charges because of lack of public interest and bean unprecedented criminal and juvenile criminal sanction imposed by the police without warning will only.this warning in 1993 that number is 311000 counts. "

Dispatch centers for medical treatment and rehabilitation of addicts,criminals Mkhtlalmshar transfer to a psychiatric hospital and mediation are other methods in this field.

In the continuation phase, Mjnylyh or private complainant may also refuse to confirm or cancel the prosecution accused or through reconciliation or mediation to end the dispute.

"Non-judicial mediation certain that the fans of such statements by the prosecution to decriminalize thought possible."

The authorities imposing punishment depriving liberty penalty may be imposed by paving the way for forgiveness and probation or semi-freedom or punishment and the authorities take steps to decriminalize the end of the week in the office and the police, in turn, may be out of role the criminal case from the criminal acts play."examples of this include the projected law enforcement agencies in working collections (corporate bodies) on the basis of their decisions, the offending employee, fired or face a warning and violation of regulations related to pollution air,tax and social security fraud to the rules,the relevant government organizations (administrative authorities such as customs and tax offenses Commission...) are examined and decisions. "

Most administrative sanctions in the form of a warning, reprimand, suspension of service, fines, and deportation...That are less severe than the penal sanction, although the two types of sanction are retractable." But when the administrative sanction or administrative punishments we usually leave aside the criminal sanction.Here we can decriminalize practical we learn. "

It is obvious that all forms of territorial delimitation decriminalize the punishment depriving liberty and avoid it as one of the most common criminal sanctions have a significant impact. However, with regard to the current realities in the field of crime can not be thought decriminalize absolute compliance but in the realm of punishment depriving liberty of thought with regard to the failure of remedies as well as disadvantages and the growing problem of the prison system and increase recidivism of limited decriminalize the groundwork for alternative measures and provide the disadvantages of the punishment depriving of freedom to the achievement of avoid the goals of prevention and social reform and restructuring assist offenders can be exploited. Obviously, this makes the concept of penalty depriving of freedom, even as a last resort in cases where other measures can not Charhsaz is criminal." with this in mind methods currently in during a clear indication that gradually scaled sanctions and a wider group of criminal elements to minimize run time in which deprivation of liberty is the last and strongest weapon in a series of criminal acts.Therefore, alternative penalties and alternative measures to prison for a series of steps towards this strategy, which gradually leads to failure are in prison.

\subsection{Disposition of Retribution Replacement Policy in Prison}

Sentence his time as a remedy against harsh punishments and corporal punishment was common, followed by the results of its implementation in most systems were in operation, preferences and lost his advantage. Increasing crime and prisoners and Tkrarknndgan the campaign failed idea amendmentand curative and preventive punishment depriving liberty ofgrowingdoubtsabout the role of punishment Melting established. As a result of anticipated measures that do not involve the disadvantages of imprisonment and control, rectification, compensation and prevention of recidivism is a good alternative to imprisonment also became necessary.

\subsubsection{Doubt Roles Punishment of Imprisonment}

Fans School imprisonment (Depriving of freedom) this punishment to be "exemplary and divisible and Charhpzyr and provider of moral reform criminals" considered desirable. But the prisoner was actually far from what was expected. Prison rather than exemplary and moral reform "from the start of crime and reoffending or for a school to have become. 


\subsubsection{Disadvantages Punishment of Imprisonment}

The effects of deprivation of liberty sentenced to short prison but rather to physical and mental integrity condemned not only the deterrent effect, and in terms of its nature but because of the diversity of the prison population and the weakening of breeding programs to the diminishing of sentencing of the feeling repentances intimidation it was also skewed the risk of recidivism increases.for this reason, despite the prediction of ways for humans to predict the minimum wage regime for prisoners in jails and prisons utility located disputed and have been taking other measures to avoid it.disadvantages that could penalties depriving freedom of expression was studied as follows:

\subsubsection{Jrmzayy Imprisonment}

Due to the lack of enough time to improve short-term punishment depriving liberty is not possible on the one hand and on the other hand the long-term risk of penalties depriving liberty incompatible with society after leaving prison sentence leads.Prison gang, also in terms of mixing all kinds of criminals, increases recidivism and solitary confinement of persons sentenced to erode the social nature creates.amendments to the regime to intimidate the less effective aspects prison and the stigma of imprisonment decent life precludes..Interestingly hope to return to.so, of criminals in prison for life on life's painful and laborious probably prefer outside.Thus, the defect penalty depriving of freedom is increased risk of recidivism that it has seen about 50 percent.

\subsubsection{Adverse Effect on the Personality of Prison and Prisoner's Family}

Not only condemned prison environment to physical and mental health but also to the high number of criminal damage and accumulation of persistent offenders incarcerated with unprecedented power of innovation and disappears with him in an artificial environment and the anti-social. To the prison sentence for the first time are sent, leaving their severe adverse effects." They conducted interviews with prisoners into prison, describing his feelings when they feel nostalgic with a bitter feeling, feeling Srkvftgy anxiety, fear, emotional distress, fear, confusion, severe anxiety, mood Castle, Nevermind (in the case of a persistent after a while after they went to prison). label throughout the life of the prison society and hatred towards society makes his pessimistic elements. prisoners in the prison lost their social status while the new Terms and Conditions sees a face that is in contrast with his social status and values. Therefore, it will not be able to fulfill their social role and functional. the new identity is inevitably followed by compliance with regulation governing prisons and the officials' actions and matched with others condemned shape. this is the issue of labeling in interactionist criminology to study the interactions between the individual and society is considered. accordingly, some individuals and groups like the criminals that the community than they react so easily labeled." According to this branch of social reaction criminology provides grounds for a label or stigma of crime against the person. it is the criminal justice system causes social stigma. (even through a criminal assembly, prohibition of residence in certain place...) And the police, judiciary and prisons, each in turn stigmatize social factors are considered.

Close family and the possibility of long-term prisoners, return flow out of prison when sentenced to life imprisonment and criminal problems and label actually makes him a decent life around. Plus unfavorable the family others be victims. Thus, instead of hostility felt remorse and returned to acceptable standards community is strengthened. that is why the prison as a punishment and loses credibility and legitimacy.

\subsubsection{Negative Economic Effects of Imprisonment}

Adverse effects on the economic dimension of punishment depriving liberty to leave prison and society and judicial system. Prison, often losing jobs and income situation in prison is disturbing. As a result, jailed and his wife and children in terms of livelihood suffered if long-term imprisonment is restricted and may also lead to the disintegration of the family center. society with the loss of its work force, especially in cases where prisoners have expertise in the fields of basic and they need community losses is irreversible. although the prison system by creating activities for inmates tried to compensate for these losses through the use of prisoners and to pay them the skills to help their livelihood there,but it can not be completely deprived of family and society the presence and function freely compensate prisoners, in addition to the prison every year on public funds and Justice imposes great costs.

Despite the development of new methods for prevention and fight against crime in most easiest and most accessible means of struggle against the prison system is still considered criminals.

Thus, with increasing conviction is punishable by depriving of freedom as well as the costs of the prison system is imposed on the public budget.

Prisoners require prisons to manage the security and administrative officials and cadres of educational,health and social workers, as well as equipment and facilities required for optimal performance penalty depriving of 
freedom. To create detention centers and prisons with different systems and equip themto establish industrial, agricultural and services and training and rehabilitation centers and Majlh convicted addicts, juvenile institution, educational programs and reforms provide food, clothing and health care, police and prison security prisons and detention centers, and other related centers account for a substantial budget every year.

\section{Conclusion}

1) The punishment of imprisonment for failure to fulfill the mission it has been assumed that the penal system and has been shown to experience today due to increased recidivism aspects of retribution and deterrence and rehabilitation and reform of the punishment of imprisonment validity and importance of is lost.

2) In terms of problems and disadvantages resulting from the use of punishment prison sentences for most offenders, as well as petty crimes, and Ksyralvqv not only beneficial for the person and society, but also led to increase in the jail population, and Tkrarknndgan offense subject. For this for punishment of imprisonment has been met with increasing skepticism. thus, especially in the second half of the twentieth century, finding remedies that can play the role of substitute for the punishment in the penal system was a priority.

3) Use alternative policies in the realm of punishment of imprisonment in many cases can reduce the jail population, and reduce recidivism as well as reduce the cost of prisons and possibly increase government revenue by imposing a fine as alternatives or use of force sentenced to community service work lead.

\section{Offers}

1) Theuse of prison alternative programs should be measured and on the observance of the principle of proportionality (a penalty) be.

2) observe the principle of proportionality, necessity requires filing with the court case is character.

3) What are the substantive and procedural criminal laws should aim to remove the central prison, to be reexamined. Sentence should be an exception in criminal law.

4) Alternative solutions such as electronic monitoring for better enforcement of sentences of imprisonment in the monitor as normal as predicted in criminal law.

\section{References}

Abdi, A. (1993). The effect of social pathology prison Prison. Tehran, light emission.

Abolfathi, A. (n.d.). The suspension of execution of punishment in criminal law and comparative law. criminal law thesis, Tehran University.

Ansel, M. (1997). Social Defense (translated by Mohammad Assyrian, Persian Alihossein Abrndabady Najafi, 2nd ed.). Tehran, Tehran University Press.

Ardabil, A. (2010). General Criminal Law (vol. II). Tehran, Press Rate.

Ardebil, M. A. (1988). Semi-freedom. legal and judicial studies, (10).

Ardebil, M. A. (1993-1994). alternatives to short prison in Iranian criminal law. legal research journal, (11-12).

Assyrian, M. (2007). alternatives to imprisonment or punishment interstitial. Navid Publications.

Bullock, B. (1999). Penology (translated by Dr. Najafi Abrandi Alihossein villages, 2nd ed.). Tehran, Majd Publications.

Convent, S. (n.d.). Penalty cash in Iranian criminal law, criminal law and criminology graduate thesis. Islamic Azad University, North Tehran Branch.

Firouzjai American Haji Hassan, a substitute for criminal detention, printing, publishing, 2008.

gozón, R. (1995). Criminology practical (translated by M. Kenya) Tehran, publisher, translator.

Janipour, L. (1997). Replacer imprisonment, criminal law and criminology graduate thesis Tehran University.

Katouzian, N. (1992). Introduction of law. Tehran, Bhnshr.

Lazrzh, C. (1992). Criminal policy (translated by Dr. Najafi Abrandi Alihossein Abadan). Tehran, Shahid Beheshti University Press.

Pica, G. (1992). Criminology (translated by Dr. Najafi Abrandi Alihossein Abadan). Tehran, Shahid Beheshti University Press.

Pradl, J. (1995). Registration criminal thoughts (translated by Dr. Najafi Abrandi Alihossein Abadan). 
Tehran,Shahid Beheshti University Press.

Sanei Prvyz. hqvq punishment Mvmy. chap Dvm. antsharat New Deal. 2010.

Shhydsany, as brightness,volume 9, Jamhalnjf Aldynyh, 1398 AH.

\section{Copyrights}

Copyright for this article is retained by the author(s), with first publication rights granted to the journal.

This is an open-access article distributed under the terms and conditions of the Creative Commons Attribution license (http://creativecommons.org/licenses/by/3.0/). 